\title{
The Funerary Stela of Ptahmes \\ from the Ramesside Period in Heliopolis
}

By

\section{Gehan Roshdy \& Khaled Mohamed Abou 'Al-Elia}

Associate Professor in the Faculty of Education, cAin Shams University

General Director of the Archaeological Site of Matariya and cAin Shams, the Ministry of Antiquities.

\begin{abstract}
This paper is concerned with the study and publication of a funerary stela of a man named Ptahmes, which was discovered in Heliopolis, and specifically in the eastern area of Ain Shams. It is currently preserved in the magazine of cArab al-Hisn at Matariya under registration $\mathrm{N}^{\circ}$. 235. It is made of limestone without any traces of color. Despite being in a good condition, some parts of the upper half of the pyramidion and the lower right corner of the stela are missing, and there are some abrasions in the upper register. The stela exhibits average quality of workmanship. It consists of two registers of incised engravings separated by a double horizontal line. The upper register contains a scene of Osiris - the only god in this stela - together with the stela's owner, Ptahmes, to whom the stela is dedicated. The second register is occupied by a group of individuals, most of whom are members of Ptahmes' family: Ptahmes himself, his mother $i r y-r$, his father $p 3-k d$, and a woman in a mourning position whose identity has not yet been identified, but who dedicated the stela itself. This article discusses the stylistic features, hieroglyphic texts, and the religious aspects of the pyramidion which tops the funerary stela, and the symbols represented on it. The analysis of the scenes and texts proves with no doubt that this stela can be dated to the New Kingdom, and more precisely to the Ramesside Period.
\end{abstract}

KEYWORDS: Ptahmes, Osiris, Pyramidion, Anubis, Ramesside Period, funerary stela, Heliopolis. 


\section{INTRODUCTION}

This funerary stela was discovered by the Egyptian inspector Essam 'El Banna during his excavation in the eastern area of Ain Shams in 1976, which was considered part of the ancient cemetery of Heliopolis named $d d t$ $3 t n t i w n w$.

\section{DESCRIPTION}

The stela measures $43.5 \mathrm{~cm}$ in height, $27 \mathrm{~cm}$ in width, and $9.2 \mathrm{~cm}$ in thickness. It is a rectangular funerary stela with a round top surmounted by a pyramidion.

\section{Pyramidion}

The pyramidion is engraved with two crouching figures of Anubis, god of the cemetery ${ }^{1}$.

\section{The Upper Register}

The god Osiris is represented at the left end of this register, beardless and seated on a cubic low-back chair ${ }^{2}$ on a rectangular base. He is depicted wearing the $3 t f$ crown and a mummy shroud, with his arms crossed over his chest and holding the $n h h 3$ scepter together with part of the shaft of another short item of insignia. According to similar scenes of Osiris, this should be the $h k 3$ scepter, a likelihood that is reinforced by similar stelae for Osiris where he is usually depicted holding both the $n h h 3$ and the $h k 3$, which has a short shaft. ${ }^{3}$

Four hieroglyphic columns occupy the space in front of Osiris. They are read as:

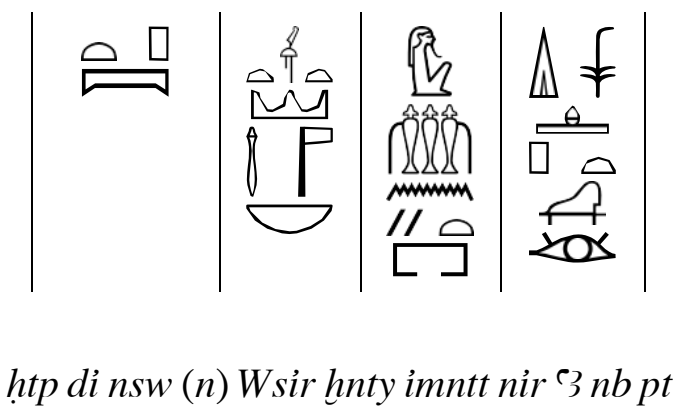

«An offering presented by the king (to) Osiris, foremost of the west, the great god, the lord of heaven».

At the far right, facing Osiris, Ptahmes stands wearing a long plain kilt, extending from his waist to below the knee, and tied with a knot around his waist. With both hands, he holds the hs jar, of which nothing is left except its rim and the holy water poured on the offerings atop a wide-based offering table that stands between Osiris and Ptahmes. Similar scenes of the jar being held by both hands are found on the stela of Aahetep JE 33238(SR14082) both hands are found on the stela of Aahetep both

\footnotetext{
${ }^{1}$ BAKRY 1962: 9.

2 This chair was widely used by gods and individuals in scenes from the Old Kingdom to the end of the pharaonic period, see: KUHLMANN 1977: 57-60.

${ }^{3}$ Such as the Ramesside Stela of ptH-nxt currently preserved in the British Museum $\mathrm{N}^{\circ}$. 288, and the Ramesside stela $N^{\circ} .1327$ stored in the Giza main magazine, see: BIERBRIER 1993: 19, PL. 59 288; 'EL-SAADY 1995: 101, 103, FIG. 1, Nº. 1.
} 
hands are found on the stela of Aahetep JE 33238(SR14082) in the Egyptian Museum in Cairo dating back to the $18^{\text {th }}$ Dynasty, ${ }^{4}$ and stela $\mathrm{N}^{\circ} .580$, which is stored at Zagreb Museum in Yugoslavia from the Late Period, ${ }^{5}$ as well as on the wall of the Tomb of Sennefer (TT96) from the Eighteenth Dynasty. ${ }^{6}$

Three hieroglyphic columns are engraved in front of and above Ptahmes' head. They are read as:

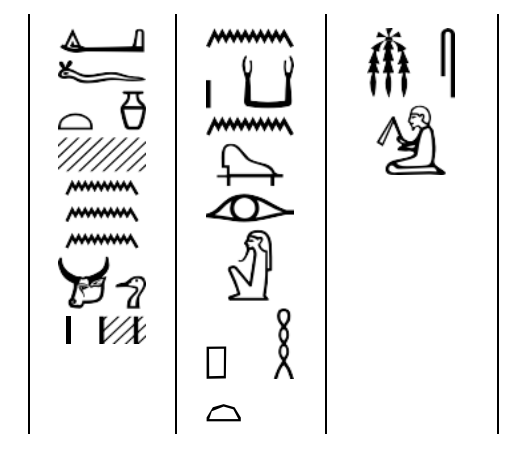

di.ft hnkt mw $k 3[w] 3 p d[w] n k 3 n$ Wsir Pth-ms

«May he grant bread, beer, water, oxen, and birds to the spirit of Osiris Ptahmes»

\section{The Lower Register}

At the far left side of the lower register, Ptahmes' mother is sitting on a chair embracing her husband, ${ }^{7}$ in such a way that her right palm touches his right elbow, which is placed over his right thigh. Her left palm rests on his left shoulder, as a symbol of the intimacy of family relations between husband and wife in ancient Egypt. In his left hand, he holds a blooming lotus flower near his nose to inhale its fragrance, since it is regarded as a symbol of resurrection. ${ }^{8}$ The woman wears a long tight garment, and a regular mass-shaped wig ${ }^{9}$ covering her shoulders and crowned by a perfume cone, while the husband is depicted wearing a long kilt, with shaved head and perfume cone. In front of the father and mother, the son is represented sitting in exactly the same position and the same size as his father.

\footnotetext{
4 cABD AL cAL 2008: 50f, FIG. 3.

${ }_{5}^{5}$ SALEH 1970: 38, No. 20.

6 TEETER 2009: 31, FIG.26.

${ }^{7}$ For more information about the embracing scene, see: LACAU 1909: PL. XIV CGC 34.23, PL. XXIX CGC 34.49, PL. XXXII CGC 34.54; MALAISE 1977: 183-198; METAWI 2008: 145; cABD ALcAL 2008: FIGS. $2,3$.

8 BRUNNER-TRAUT 1980: 1092; HARTWIG 2004: 89.

${ }_{9}^{9}$ ROBINS 1999: 64.
} 
Eight hieroglyphic columns are engraved above Ptahmes as well as his mother and father. They are read as:

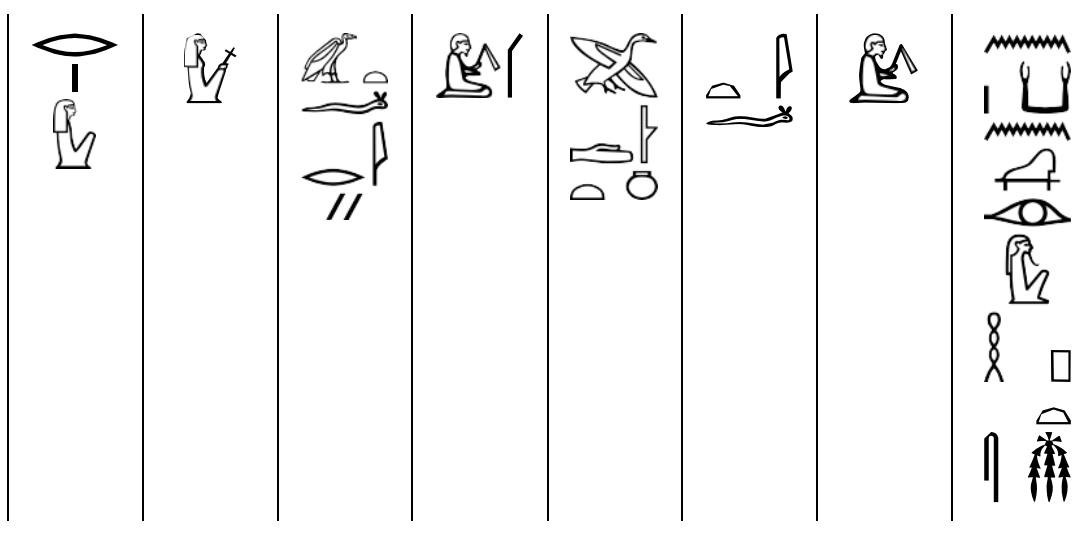

$n k 3 n$ Wsir Pth-ms it.(f) p3-kd mwt.f iry-r

«For the spirit of Osiris Ptahmes, his father PA- qed, his mother Iry-r»

At the right end of this register, a woman stands wearing a long tight topless garment and a wig tied up by a ribbon. In her right hand, she holds a jar, out of which she pours the holy water on the offerings accumulated upon the offering table located in front of Ptahmes and his parents, whereas she raises her left hand above her head in a mourning position.

In front of her head are two columns of hieroglyphs. They read as:

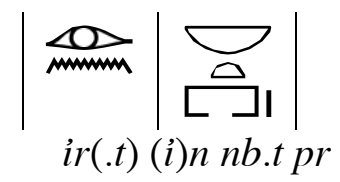

«Made by the lady of the house»

Her name appears in the space separating her from the offering table, and reads as follows:

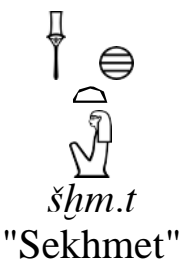

\section{COMMENTARY}

\section{Pyramidion}

Funerary stelae surmounted by a pyramidion were common in theRamesside period $^{10}$. It is to be noted that Osiris is the main and almost the sole deity

\footnotetext{
${ }^{10}$ BAKRY 1962: 9f, 11, 14, PLS. I, II; RADWAN 1987: 223-228, PLS. I- VI; MOURSI 1988: 59-61, FIGS.1- 2.
} 
that is represented in this kind of stelae, including that studied here. ${ }^{11}$ The ancient Egyptian took several measures to achieve resurrection in the other world, assimilating his destiny with that of the shining sun. This was usually attained through the representation of the pyramidion on top of stelae as a solar symbol (bnbn), ${ }^{12}$ and by depicting Osiris himself, who is regarded as the sun of the other world. ${ }^{13}$ This is in addition to some of the symbols represented on the pyramidion, which are aimed at helping with resurrection, such as the seated jackal to guard the stela and its owner. The jackal appeared as a decorative element on top of funerary stelae from the $12^{\text {th }}$ dynasty. ${ }^{14}$ Its presence guarantees the arrival of sunlight, since it pulls the sun boat through the other world, in Osiris' realm. ${ }^{15}$ Some stelae have a pyramidion on their rounded top, such as the stela of $K y-n f r$, which is currently preserved in the Pushkin Museum in Moscow ( $\left.\mathrm{N}^{\circ} .79\right)$ and dates back to the $19^{\text {th }}$ dynasty. ${ }^{16}$ Another example is the stela of $p(3)-n-n b w$, which is currently in the British Museum $\left(\mathrm{N}^{\circ} .372\right)$ from the same period, ${ }^{17}$ and the stela preserved in the Giza main magazine ( $\left.{ }^{\circ} .1330\right)$ from the Ramesside period..$^{18}$ There are other stelae as well with the representation of the jackal on the pyramidion, such as stela $\mathrm{N}^{\circ} .593$ in Zagreb Museum in Yugoslavia dating back to the Ramesside period ${ }^{19}$, the stela of Amun chantress $n-m-m r$ which is now preserved at the Tel Basta magazine $\left(\mathrm{N}^{\circ} .399\right)$ and belongs to the same era, ${ }^{20}$ and the stela of $p 3-s r$ currently preserved in the magazine of Mattaria $\left(\mathrm{N}^{\circ} .3644\right)$ and dating to the $19^{\text {th }}$ dynasty. ${ }^{21}$

\section{Pouring Holy Water on the Offerings}

The purpose of pouring holy water on the offerings, which is known as the stj ritual $^{22}$, is not limited to purification only, but enabled the renewal and resurrection cycle for these offerings ${ }^{23}$ to ensure the granting of life and luxury to the deceased and gods in the other world. ${ }^{24}$ The scene of pouring holy water on offerings is represented on a stela dating back to the New Kingdom, which was discovered in Tell Basta and is currently preserved in the magazine of Tell al- Yahudia (B 687). ${ }^{25}$ Another similar stela, which was found in Heliopolis, is currently in Giza magazine and dates to the $18^{\text {th }}$

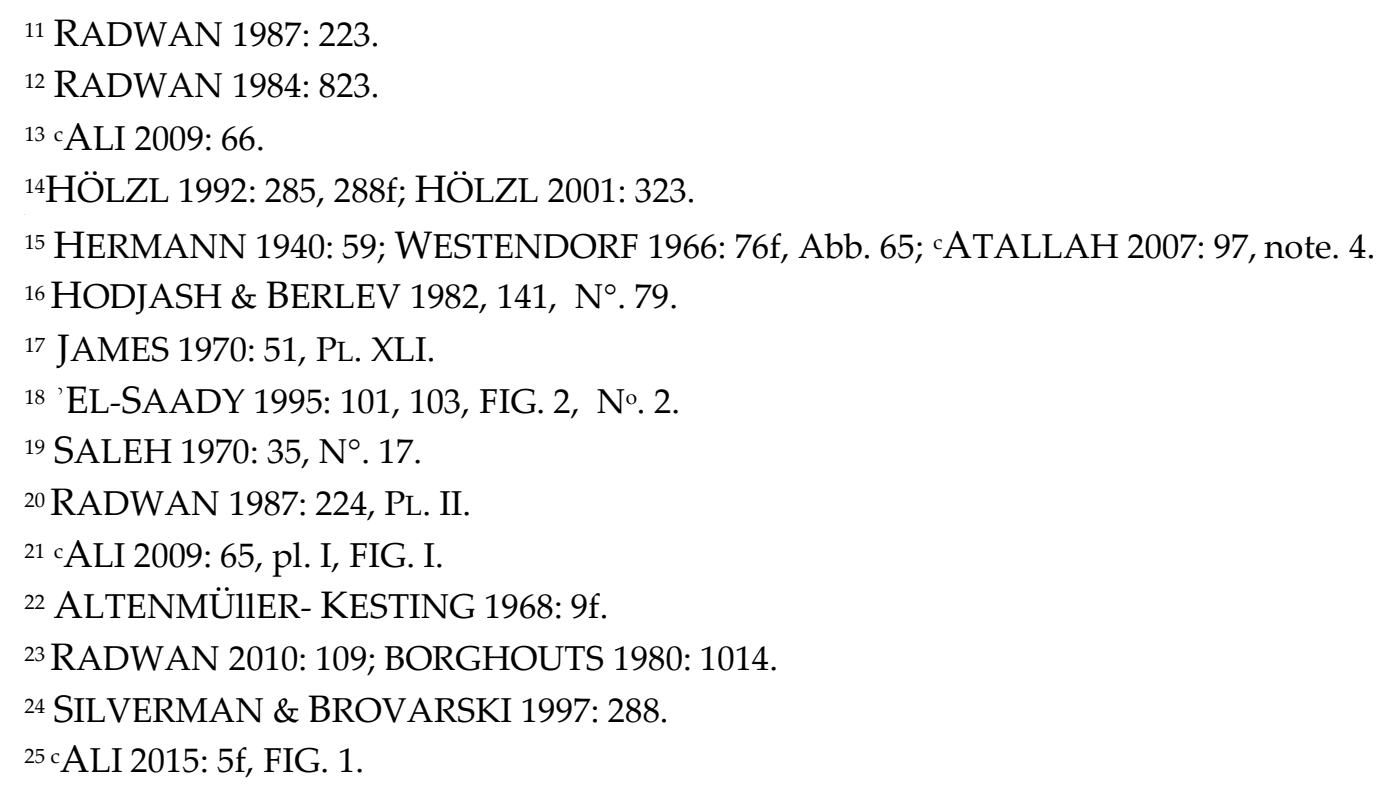


dynasty, ${ }^{26}$ in addition to the $19^{\text {th }}$ dynasty stela of $R^{e}-m s$ in the British Museum (No.139). ${ }^{27}$

\section{The Kilt of Ptahmes}

The style of the kilt that Ptahmes wears was widely used in the New Kingdom, especially in the Ramesside Period. Sometimes, these kilts are depicted with pleats, while at other times, they are represented plain, as in stelae $\mathrm{N}^{\circ}$. 549, 772 and 1725 in the British Museum ${ }^{28}$, as well as stelae $\mathrm{N}^{\mathrm{o}_{\mathrm{s}}}$. S.68, S. 72,76 and 112 in Leiden Museum. ${ }^{29}$

\section{Individuals' Chair Model}

The type of chair seen on the stela was very common in scenes of the New Kingdom, ${ }^{30}$ as is clearly displayed on the walls of the Rekhmire tomb (TT 100) which dates to the $18^{\text {th }}$ dynasty, ${ }^{31}$ and the Amenhotep Asisi tomb (TT 75) of the reign of Thutmose IV, ${ }^{32}$ as well as on the New Kingdom stela CGC 34185 in the Cairo Egyptian Museum ${ }^{33}$.

\section{Inhaling the Fragrance of Lotus Flower}

The motif of smelling the lotus flower was frequently depicted in private stelae of the New Kingdom. ${ }^{34}$ This scene first appeared on stelae in the Middle Kingdom ${ }^{35}$, as seen in a stela of the late Middle Kingdom discovered in Abydos and now in the National Museum of Antiquities in Athens (L132). ${ }^{36}$ This scene is also displayed on the stela of $D d w$-rbk which is in the Cairo Egyptian Museum (TN 30.10.17.5) from the same period, ${ }^{37}$ and the stela of Pth-m-wi3 in the British Museum (No. 167), dating to the $19^{\text {th }}$ dynasty. ${ }^{38}$ The New Kingdom stela CGC 34059 in the Cairo Egyptian Museum ${ }^{39}$ gives a parallel to men being shown inhaling the lotus flower, as is the case in the stela of the current study.

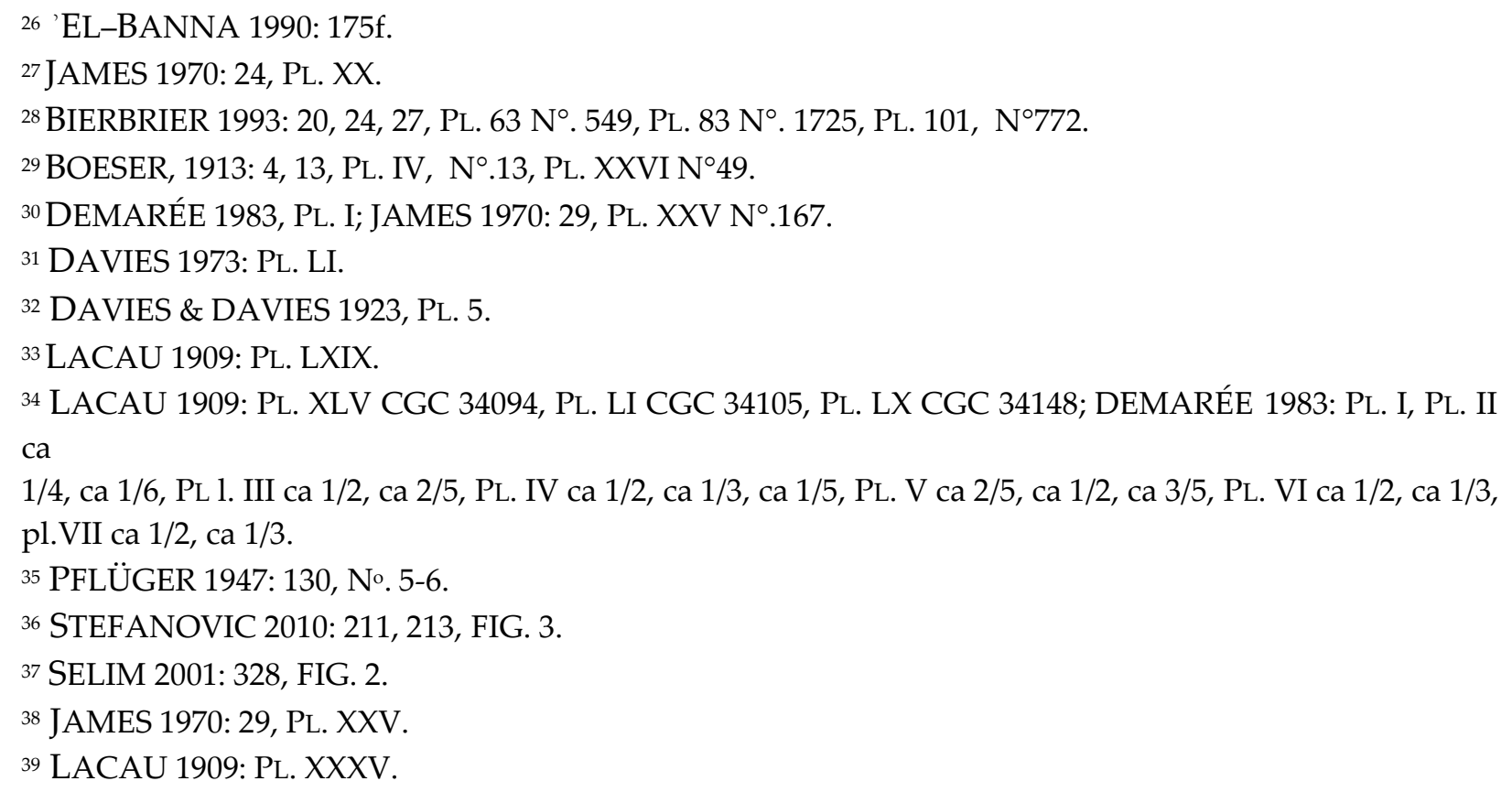




\section{The Mourners}

The scene of the mourners is less commonly represented in funerary stelae, despite the fact that mourners ( $\underline{d r y t})$ are usually depicted in the scenes of funerals on the walls of tombs from the time of the Old Kingdom onwards. ${ }^{40}$ The topless garment of the mourner represented on the current stela is one of the characteristic features of mourners' costumes in the New Kingdom. ${ }^{41}$ Similar scenes of mourners are found on such stelae as that of Dhwty, which was discovered in Saqqara and is now in the National Museum of Antiquities in Leiden (V 51). It dates to the late $18^{\text {th }}$ dynasty or the early $19^{\text {th }}$ dynasty. ${ }^{42}$ The $19^{\text {th }}$ dynasty stela of $N f r-C b w$ and $N f r$-rnpt, which is preserved in the British Museum $\left(\mathrm{N}^{\circ}\right.$. 305) is another instance. ${ }^{43}$ It is worth noting that the mourning scene was not confined to women only; men were also sometimes represented displaying grief by putting one hand over the head, as is the case with the stela of $\mathrm{H3r}$ in the British Museum ( $\left.\mathrm{N}^{\circ} .549\right)$, of the $19^{\text {th }}$ or $20^{\text {th }}$ dynasties. ${ }^{44}$

\section{Discussion}

There are several points to note regarding the stela under consideration. First, it exhibits average quality of workmanship, which indicates that the owner belongs to the lower class in society. Second, the individuals are represented barefoot. Third, the stela is devoid of sons despite the fact that the ancient Egyptians were obsessed with the representation of their offspring. Such obsession is still present until now, which makes it possible either that Ptahmes was single, widowed, or barren; or that he died a short time after he married and could not have children. Fourth, there is no mentionin the stela of professional state titles, which proves that the individuals represented belong to the lower class. Fifth, although the identity of boththe father and mother of Ptahmes is recognized through the hieroglyphic writing $m w t . f i t .(f)$, the woman in the mourning position, who dedicated the stela to Ptahmes, has not been identified. The same holds true for the $19^{\text {th }}$ dynasty stela of $p 3-R^{\mathrm{C}}$ which is currently in the Pushkin Museum in Moscow $\left(\mathrm{N}^{\circ} .82\right)$, where the phrase «ir n nbt pr h3y" » «made by the lady of the house Hay» appears without the identification of the dedicator of the stela ${ }^{45}$. Finally, the individuals in the stela are depicted as elongated and thin, which is one of the characteristics of the Ramesside period in general, and the reign of Ramses II in particular. ${ }^{46}$ This is obviously represented in the stelae of the British Museum, for example $\left(\mathrm{N}^{\text {os }} .309,321,549,796,1184\right)^{47}$.

\footnotetext{
${ }^{40}$ SIMPSON 1976: 22, PLS. XVIII, XIX; DAVIES \& GARDINER 1920: 19f; DZIOBEK 1992: 80f, PL. 25; ASSEM 2012: 18.

${ }^{41}$ GREEN 2001: 277.

42 cAFFARA 2010: 147, 153, FIG. 1.

${ }^{43}$ JAMES 1970: 36, PL. XXXII, N. 305.

${ }^{44}$ BIERBRIER 1993: 20, pl. 63, No. 549.

${ }^{45}$ HODJASH \& BERLEV 1982: 141， $\mathrm{N}^{\circ} .82$.

${ }^{46}$ RUSSMANN 2001: 182.

${ }_{47}$ BIERBRIER 1993: 19, PL.61, No. 309, 20, Pl.63, No. 549, 22, Pl.71, N. 321, 22, PL. 73, No. 796, 24, PL. 85, $\mathrm{N}^{\circ} .1184$.
} 
- htp-di-nsw: The formula htp-di-nsw was written with the following order of signs in this form $\neq \Delta \frac{\theta}{\square 0}$ in the Second Intermediate Period, ${ }^{48}$ and it was commonly written as such also in the New Kingdom, ${ }^{49}$ especially in the $19^{\text {th }}$ Dynasty. ${ }^{50}$ This is clearly depicted on the New Kingdom stela CGC 34.85 in the Cairo Egyptian Museum, ${ }^{51}$ as well as the base of the statue of Pached that is currently in Louvre Museum (E 12682) from the same period ${ }^{52}$. Another case in point is Stela $N^{\circ} .1363$ discovered in Heliopolis which is now preserved in the Giza main magazine, dating back to the Ramesside Period. ${ }^{53}$

\section{The Writing of the Name of Osiris:}

It was not until the reign of Senusret III in the late $12^{\text {th }}$ dynasty that the portable seat $\overbrace{}^{54}$ was part of the name of Osiris in the offering formula $h t p-d i-n s w .{ }^{55}$ In the Middle Kingdom, the name was written in such a way that the portable seat was frequently followed by the eye sign, whereas in the New Kingdom it was sometimes written by the eye sign followed by the portable seat ${ }^{56}$. The way of writing the name of Osiris with the portable seat followed by the eye sign can be found on other similar stelae, such as stela CGC 34.24 , in the Cairo Egyptian Museum, belonging to the New Kingdom, ${ }^{57}$ and stela $\mathrm{N}^{\circ} .31663$ in the Field Museum of Natural History in Chicago from the Ramesside Period. $^{58}$

It is worth mentioning that inscribing the eye sign with eyelashes, as is shown in the name of Osiris in this stela, started from the 18th dynasty. ${ }^{59}$ Archaeological sources with this features include the $18^{\text {th }}$ dynasty statue of Khaemwese and Tamwadjsi in the Museum of Khartoum ( $\left.\mathrm{N}^{\circ} .0956\right) ;^{60}$ the $19^{\text {th }}$ dynasty stela of $\mathrm{Neber}^{61}$, currently in the Berlin Museum ( $\left.\mathrm{N}^{\circ} .20377\right)$; the stela of $p n-b w y$ in the British Museum ( $\mathrm{N}^{\circ} .1466$ ), which is dated back to the same era ${ }^{62}$; the stela of P3-iry which is currently in Pushkin Museum in Moscow ( $\left.\mathrm{N}^{\circ} .86\right)$ and belongs again to the $19^{\text {th }}$ dynasty ${ }^{63}$; and the stela of $k n-h r-h p \breve{s}$ which is in the British Museum (No. 278) and dates to the $20^{\text {th }}$ dynasty ${ }^{64}$.

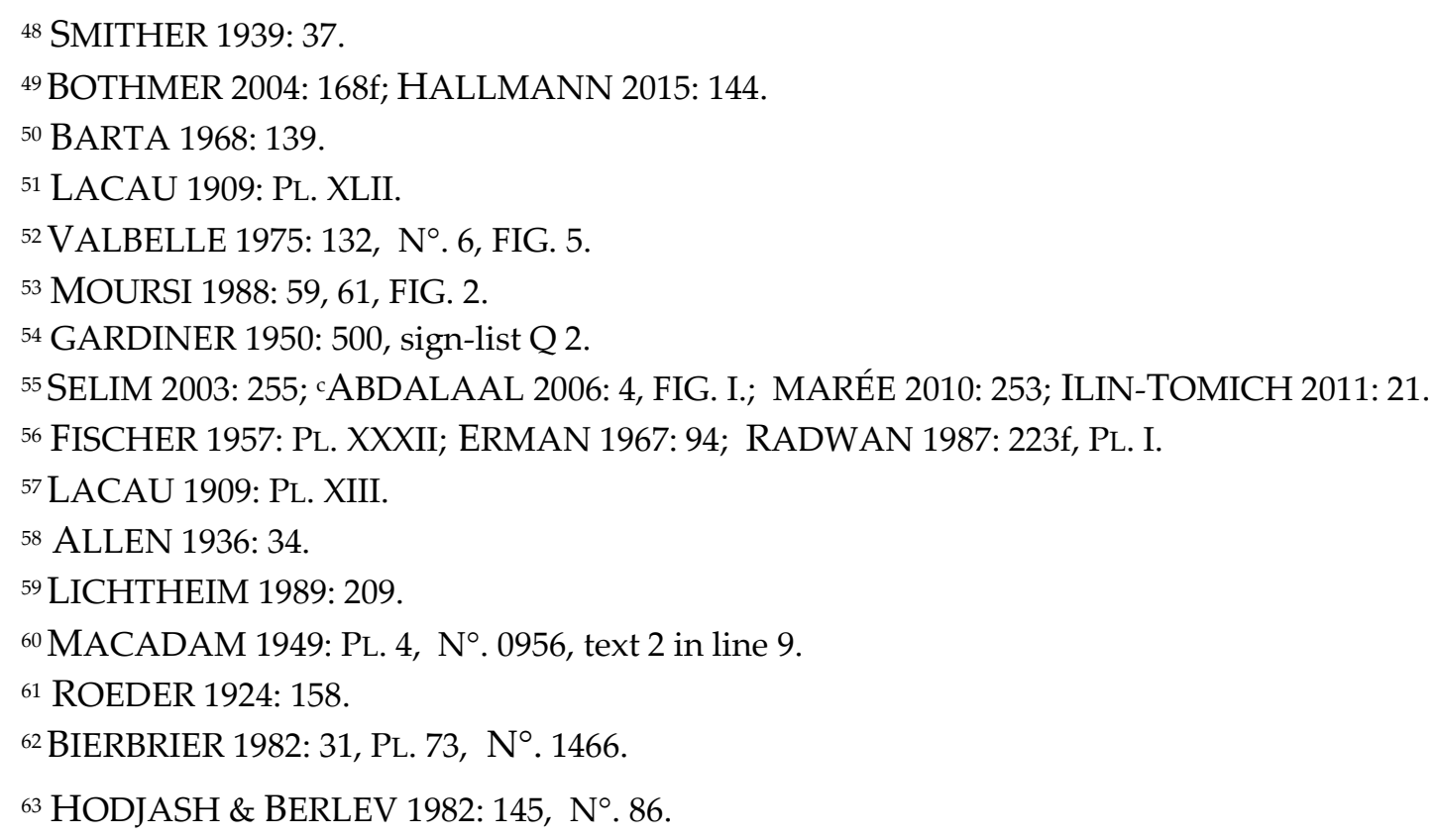


- hnty-imntt: This is one of the titles associated with Osiris in the offering formula, referring to him as the funerary god of protection ${ }^{65}$. It was first given to Osiris in the Old Kingdom ${ }^{66}$, as mentioned in spell 2020 and 2021 in the Pyramid Texts ${ }^{67}$. In the Old

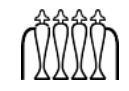

Kingdom, the sign

was written with four water pots, whereas it was written with three water pots from the Middle Kingdom onwards and represented as 10000060 sign $\Gamma_{\text {devel }}$ Khentaka at Saqqara in the $6^{\text {th }}$ dynasty ${ }^{69}$. With regard to the determinative of this title 12), it started to appear less until it disappeared in the late Middle Kingdom ${ }^{70}$. It is worth noting that the sign $p r$ mentioned as a determinative in the word hnty in the title hnty-imntt associated with Osiris on the current stela appears in the same title on stela S.71, $\mathrm{N}^{\circ}$. 108 in the Leiden Museum, which is dated to the $19^{\text {th }}$ dynasty ${ }^{71}$.

-nir-3: The title nir-3 was associated with Osiris ${ }^{72}$ since the Old Kingdom, although it was rare at this time ${ }^{73}$. Osiris is referred to by this title in the Pyramid Texts in spell $200 \mathrm{~b}^{74}$. However, since the $12^{\text {th }}$ dynasty, and especially the reign of Senusret I onwards, this title was more commonly associated with Osiris and used more widely than before $^{75}$.

-nb-pt: This title ,the lord of heaven" dates back to the Old Kingdom, as Leitz has noted, and it continued to appear in all subsequent periods, from the Middle Kingdom to the Greek-Roman Period. ${ }^{76}$ It was given to a number of ancient Egyptian gods, including Osiris, who was associated with this title since the time of the Old Kingdom, as is indicated in texts in the Tomb of Mahw in Saqqara, which dates to the $6^{\text {th }}$ dynasty ${ }^{77}$.

- di.f: the sentence «di.f» (He may grant) was first used in the offering formula in the $12^{\text {th }}$ dynasty, and is an important criterion of dating since it never appeared in

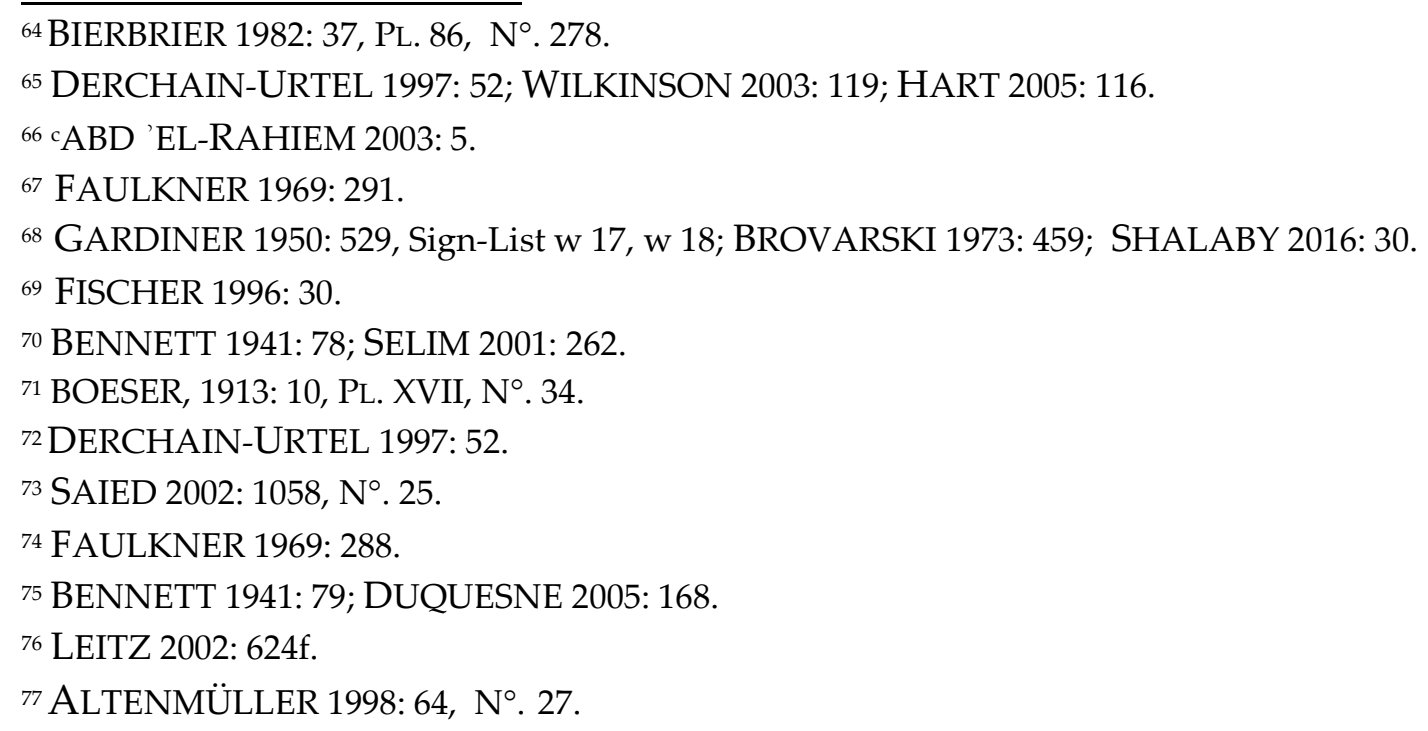


periods prior to this ${ }^{78}$. The reason for the addition of this sentence may be to clarify the belief that the offerings were given by the king to god, who then in turn gives them to the deceased ${ }^{79}$. It is worth mentioning that the sentence «di.f» mentioned in this stela is not followed by prt-hrw, which literally means the voice goes forth; i.e. invocation ${ }^{80}$, and this is something which is rare. The writing of di.f without prt-hrw does occur, though, in similar stelae, such as $\mathrm{N}^{\mathrm{o}}$. 585 in the Zagreb Museum in Yugoslavia of the Middle Kingdom $^{81}$, and stela CGC 34.81 in the Cairo Egyptian Museum from the New Kingdom $^{82}$.

- $\boldsymbol{i} h n k t k 3[w]$ : The lists of offerings comprise, as expected, both bread, which has a symbolic significance associated with the continuity of life in the other world ${ }^{83}$, and beer, which started to appear in the lists of offerings on stelae from the $2^{\text {nd }}$ dynasty ${ }^{84}$. In addition, the presence of the head of the ox in these lists has a symbolic significance associated with eradication of evil through the journey of the deceased in the other world, since the ox head represents the cutting of the head of Set and his followers in his struggle with Osiris ${ }^{85}$.

- $n k 3 n$ : The phrase $n k 3 n$ im3hy (for the spirit of the revered ...) was first written before the title and the name of the deceased in the offering formula $h t p$-di-nsw on stelae dating back to the early $12^{\text {th }}$ dynasty ${ }^{86}$. However, Hassan Selim argues that this phrase was found on some stelae in the reign of Intef II or Mentuhotep II in the $11^{\text {th }}$ dynasty ${ }^{87}$. It is worth mentioning that the title im3hy qrim3hw started to disappear after $n k 3 n$ in the reign of Senusret $\mathrm{I}^{88}$ before totally disappearing in the late $12^{\text {th }}$ dynasty from the reign of Senusret III onward ${ }^{89}$. The disappearance of this title is attributed to change in religious belief, where the deceased was no longer given the worldly title of revered, but became a spirit in reference to his destiny in the other world ${ }^{90}$. Other stelae which resemble this stela in terms of how the phrase $n k 3 n$ is written without the title «revered» include that of $N b(=j)-p w-z j-n(. j)-w s r . t$ in the British Museum ( $\left.\mathrm{N}^{\circ} .101\right)$ dating back to the reign of Senusret $\mathrm{III}^{91}$, and $\mathrm{the} \mathrm{New} \mathrm{Kingdom}$ stela CGC 34045, which was discovered in Thebes and is now in the Cairo Egyptian Museum ${ }^{92}$.

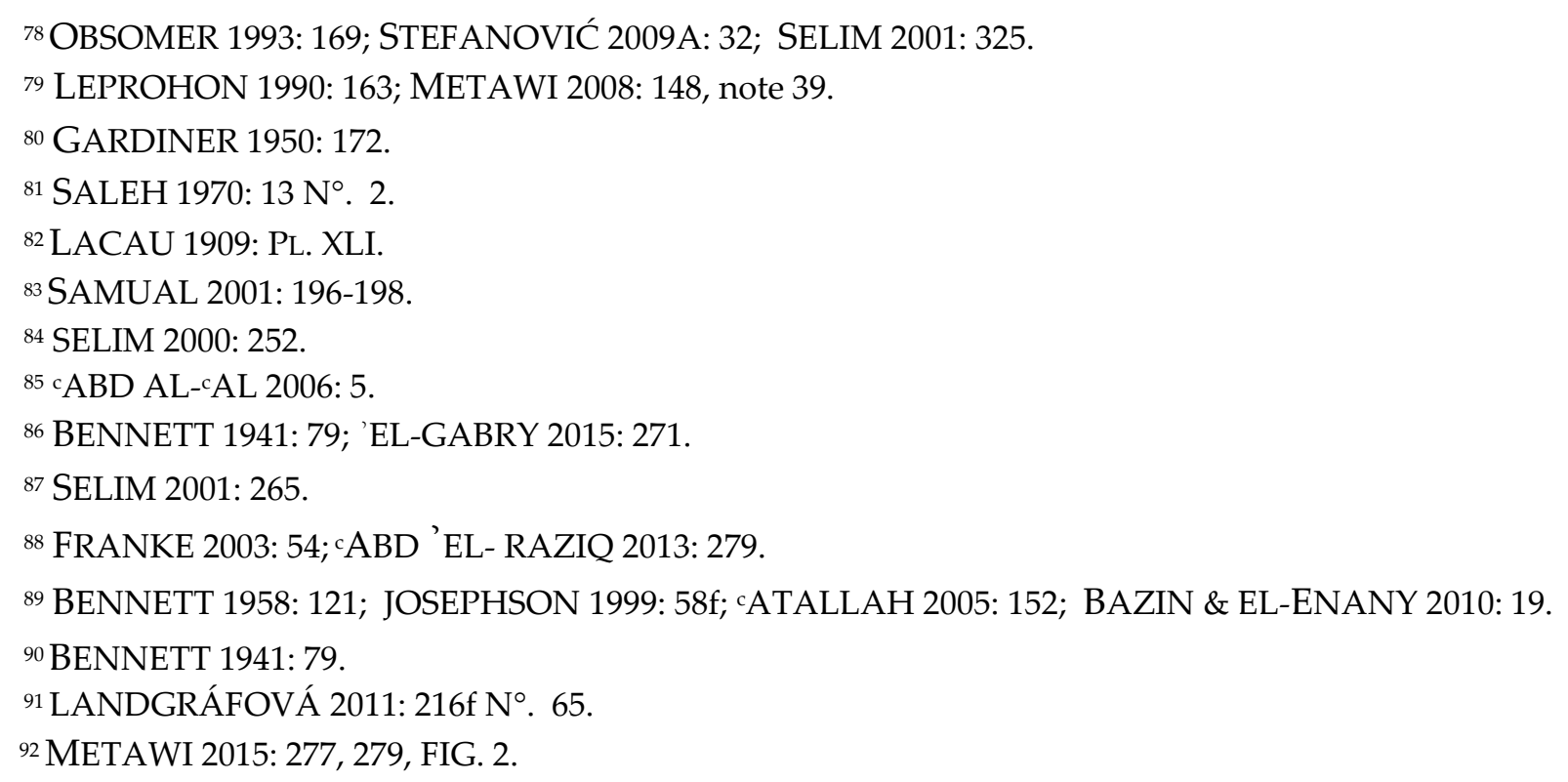


- The use of the name of Osiris added before the names of kings to mean the deceased dates to the $5^{\text {th }}$ dynasty, as mentioned in the Pyramid Texts of the kings of the $5^{\text {th }}$ and $6^{\text {th }}$ dynasty ${ }^{93}$. At the beginning of the Middle Kingdom, the name of Osiris was added before the names of dead individuals in hope that they would be resurrected like Osiris, the symbol of resurrection ${ }^{94}$. Other stelae that similarly write the name of Osiris before the names of individuals include that of Amenemhat discovered in Saqqara, which is currently in the Cairo Egyptian Museum TN 10/6/24/8(SR 11732) and dates to the late $18^{\text {th }}$ dynasty ${ }^{95}$; the stela of Hatyai in the Cairo Egyptian Museum (JE 25641) from the Ramesside Period ${ }^{96}$; the stela of Suti dating to the same era and preserved in the same museum (JE $8781(5 / 11 / 24 / 4))^{97}$; and the $18^{\text {th }}$ or early $19^{\text {th }}$ dynasty stela of $\underline{D} h w t y$, in the National Museum ofAntiquities in Leiden ${ }^{98}$.

- nbt-pr: This title, which refers to the status of women as being married, started to appear on stelae in the late Middle Kingdom ${ }^{99}$, especially in the reign of Amenemhat III. It continued to appear on most funerary stelae in the following periods ${ }^{100}$. Obsomer and Ilin-Tomach mention that the title wasdodisplayed on some stelae prior to Amenemhat's rule ${ }^{101}$. Among the stelae displaying this title are stela $\mathrm{N}^{\circ}$. 53, which was discovered in the area of Serabit el-Khadim and dates back to the reign of Amenemhat $\mathrm{III}^{102}$, and the stela of $p A-R a$ in the Pushkin Museum in Moscow dating to the $19^{\text {th }}$ dynasty ${ }^{103}$. This is in addition to the stela discovered in Kafr 'El-Gabl and currently in the Giza main magazine $\left(\mathrm{N}^{\circ} .45\right)$, dating to the reign of Ramses $\mathrm{II}^{104}$, and the $25^{\text {th }}$ dynasty stela of $\mathrm{Hr}$ $n x t$ preserved in the Cairo Egyptian museum (JE 18651) ${ }^{105}$.

- $\operatorname{ir}(\boldsymbol{i}) n$ : This phrase is displayed in several funerary stelae which are dated to the New Kingdom, especially the Ramesside Period ${ }^{106}$, and means «made by»107. It is usually followed by the name of the dedicator of the stela.

\footnotetext{
${ }^{93}$ HART 2005: 116.

${ }_{94}$ LURKER 1980: 93; WILKINSON 2003: 122.

95 cASSEM 2006: 63f, 66.

${ }^{96}$ GABALLA 1979: 46, 50, FIG. 2.

${ }^{97}$ GABALLA 1979: 42, 50, FIG. 1.

98 cAFFARA 2010: 147, 151, FIG. 1.

${ }^{99}$ SMITHER \& DAKIN 1939: 160, PL. XX, N. 2; PESTMAN 1961: 11, No. 1; STEFANOVIĆ 2009 B: 7-9; ROBINS 1979: 208, Nº. 4; WARD 1982: 99, Nº. 823; LABRIQUE 2003: 270, PL. I a; SALEH 2007: 71.

100 FREED 1996: 331.

${ }^{101}$ OBSOMER 1993: 166f; ILIN-TOMICH 2011: 126.

102 'AL-AYEDI 2005: 57f, FIG. 1.

${ }^{103}$ HODJASH \& BERLEV 1982: 141, №. 82.

104 cABD 'EL-cAL 1990: 7, PL. 1, FIG.1.

105 cABD 'EL- MAGIUD 2015: 77f, pl. 1.

106 STEWART 1976: PL. 33 №. 3, Pl. 37, Nº. 3, Pl. 38, №. 2; HODJASH \& BERLEV 1982: 141, Nº. 82, 142 $\mathrm{N}^{\circ} .84$.
} 
Examples of stelae with this phrase are stela CGC 34133 of the New Kingdom, which is currently in the Cairo Egyptian Museum ${ }^{108}$, and the stela of sny-nfr dating back to the $18^{\text {th }}$ dynasty $^{109}$. Another is the stela of $\boldsymbol{H}^{\mathrm{c}}$-m-tr family and the scribe $k n-h r-\underline{h} p \check{s}$. f, preserved at the Chicago Institute of Oriental Studies (E 14315), from the reign of Ramses $\mathrm{II}^{110}$. A further instance is the stela discovered in Heliopolis which is now in Ny Carlsberg Glyptothek, Kopenhagen (AEIN 589), and dated to the $20^{\text {th }}$ dynasty ${ }^{111}$.

It is worth mentioning that by placing the title nbt-pr before the name of the woman depicted in the mourning position, it is argued that the woman who dedicated the stela to Ptahmes is most likely to be his sister or wife, given the fact that this title is only given to married women. An example of stelae that display the phrase (ir $(t)(i) n$ snt.f $n b t$ $p r$ ) «made by his sister, the lady of the house» in the presence of his wife is the $18^{\text {th }}$ dynasty stela (TN 2/11/24/1) in the Egyptian Museum ${ }^{112}$. Stela British Museum 183, also of the $18^{\text {th }}$ dynasty, has the phrase (ir(t) (i)n snt.sn) «made by their sister» clearly spelled out $^{113}$. Among the stelae which display the title $n b t-p r$ followed by the name of the wife of the stela owner are that of $k 3-s 3$, in the Cairo Egyptian Museum and dating to the $19^{\text {th }}$ dynasty $^{114}$, as well as the stela of $M r-n \underline{d m}$ in the British Museum ( $\left.{ }^{\circ} .1188\right)$, which belongs to the same era ${ }^{115}$. The lady in the mourning position might thus be Ptahmes' wife, who dedicated this stela in honor of her husband and his parents.

\section{Personal Names}

The personal names mentioned on this stela are attested in Ranke, namely Pth-ms and $p 3-k d$, which he reads as $p 3-k d(w)$, iry-r and shmt, which all appeared in the New Kingdom ${ }^{116}$. The name Pth-ms was popular in ancient Egypt and was written on many monuments, such as the $18^{\text {th }}$ dynasty Book of the Dead of $n b-s n y$, which was discovered in Saqqara and is now in the British Museum (EA 9900/32) ${ }^{117}$. It is also mentioned on several New Kingdom stelae in the Leiden Museum Nos. S. 56, No. 20, S.73, No. 120, S. $78, \mathrm{~N}^{\circ} \cdot 124^{118}$.

\footnotetext{
${ }_{107}$ ERMAN \& GRAPOW (Eds) 1982: Wb. I, 111 Nº. 7; SEIPEL 1989: 270, Nº 441.

${ }^{108}$ LACAU 1909: pl. LV.

${ }^{109}$ DORN \& PAULIN-GROTHE 2009: 9f, Abb.2.

110 TEETER 2014: 147, 151.

${ }_{111}$ MOURSI 1987: 230, 231, Abb. 3.

${ }_{112}$ GABALLA 1979: 47, 50, FIG. 3.

113 JAMES 1970: 19, PL. XV.

${ }_{114}$ BAKRY 1962: 10f, 14, pl. II.

${ }^{115}$ BIERBRIER 1982: 23, pl. 54.

${ }_{116}$ RANKE 1935, 41, No. 28, 120, No. 2, 140, No. 9, $319, \mathrm{~N}^{\circ} .21$.

117 RUSSMANN 2001: 195.

${ }_{118}$ BOESER 1913: 2, 8, Index C N XX, tafs. VIII, No. 5, XV, Nº. 27, XVIII, No. 28.
} 
Furthermore, the names shmt and $p 3-k d$ appear on the stela of $H u y$, which is currently preserved in the same museum S.67, $\mathrm{N}^{\circ} .75$ and dates back the $18^{\text {th }}$ dynasty ${ }^{119}$. As far as the name iry-r is concerned, it is mentioned on the base of a New Kingdom statue of a dog made of black granite, which is currently preserved in the Alexandria Museum, Hall $\mathrm{N}^{\circ} .10$ with registration $\mathrm{N}^{\circ} .1933^{120}$.

\section{Remarks on the Texts of the Stela}

-The writing method of the word hnty with the pr sign in the title "hnty imntt" is rare and different from its writing method in $\mathrm{WB}^{121}$, Faulkner ${ }^{122}$ and Leitz ${ }^{123}$.

- It is possible to complete the vertical strokes, which refer to plurality and were first used in the second half of the $11^{\text {th }}$ dynasty ${ }^{124}$, attached to the head of the ox and the

bird in the abraded portion to read as $k 3 w 3 p d w$. This is a frequently occurring structure of the offering formula in similar texts, as is represented on stela S. $65, \mathrm{~N}^{\circ} .60$ in the Leiden Museum which dates back to the $18^{\text {th }}$ dynasty ${ }^{125}$, as well as the stela( $\left.\mathrm{N}^{\circ} .700\right)$ stored in the British Museum from the Ramesside Period ${ }^{126}$.

-The epithet $m 3^{c} h r w$, which means 'justified', does not appear after the name of Ptahmes, though it was frequently mentioned after the name of the owner of the stela in reference to his death ${ }^{127}$.

-It is to be noted that the artisan of the stela wrote the word " $k d$ " in the personal name $p 3$ $k d$ by using the sign, whereas Ranke refers to " $k d^{*}$ in the same name by the papyrus scroll

. The same holds true for stela S.67, $\mathrm{N}^{\circ} .75$ that is preserved in Leiden Museum, and dates to the $18^{\text {th }}$ dynasty ${ }^{129}$. Furthermore, $W B$ mentions the word $k d$ with the papyrus scroll and " $t^{1130}$. This indicates that the ancient Egyptians employed a variety of ways to write the word $k d$, by using the papyrus scroll or " $t$.

\section{DATING OF THE STELA}

To conclude, this stela dates to the time of the New Kingdom, and precisely the Ramesside Period, according to the following evidence, most of which has been mentioned above:

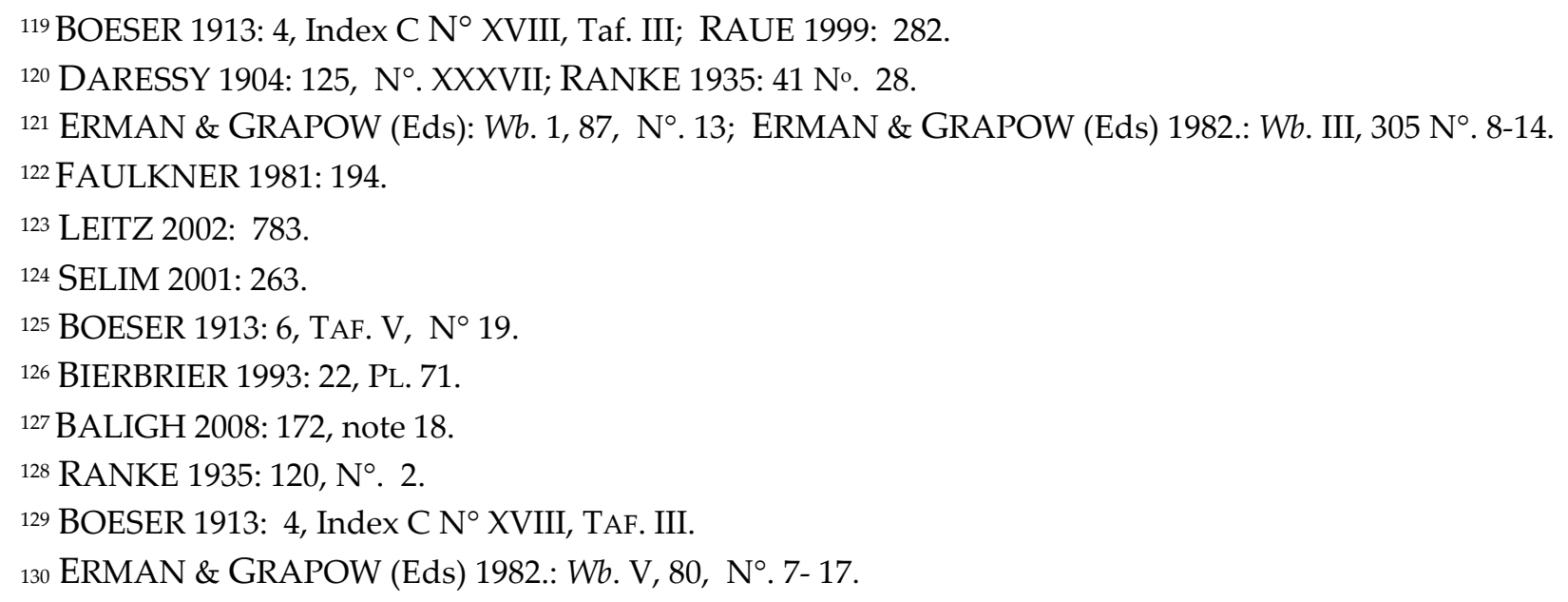


The representation of the perfume cone on the head of men and women appeared in the $18^{\text {th }}$ dynasty onwards ${ }^{131}$. In addition, the kind of perfume cone depicted in this stela was common in the $19^{\text {th }}$ dynasty ${ }^{132}$.

The model of the chair on which the individuals sit was prevalent in theNew Kingdom.

The garment of the mourner epitomizes the style of mourners' costumes as they appeared in the New Kingdom.

The representation of the pyramidion on the top of funerary stelae was very common in the Ramesside Period, especially the $19^{\text {th }}$ dynasty.

The depiction of the body of individuals as elongated and thin is characteristic of the Ramesside Period.

The kilt of Ptahmes was widely worn in the $19^{\text {th }}$ dynasty.

The writing of the offering formula htp-di-nsw on this stela was common in the New Kingdom.

The personal names mentioned in this stela first appeared in the New Kingdom. The phrase "ir (i) $n$ " (made by) was widespread on funerary stelae in the New Kingdom.

The appearance of the eye sign with eyelashes was used in writing from the $18^{\text {th }}$ dynasty onwards.

\section{HOW TO CITE}

Roshdy, G. \& Mohamed, K. «The Funerary Stela of Ptahmes from the Ramesside Period in Heliopolis», Journal of the General Union of Arab Archaeologists, vol. 6/1, 2021. Doi: 10.21608/jguaa2.2020.44883.1038 gihanroshdy509@outlook.com; kabualala@yahoo.com

\footnotetext{
${ }^{131}$ DEMARÉE 1983: PLS. II ca1/4, VI ca 1/4, VII ca 1/2, XII ca 1/3; GREEN 2001: 73.

${ }^{132}$ CHERPION 1994: 79-81
} 


\section{Gehan Roshdy \& Khaled Mohamed Abou al-Elia}

\section{BIBLIOGRAPHY}

'ABD'AL- 'AL, A. M.: «Three Unpublished Stelae from the Egyptian Museum, Cairo», In Supplément aux Annales du Service des Antiquités de L' Égypte, Cahier Nº. 34, vol. 1, Edited by ZAHI A. HAWASS \& KHALED A. DAOUD , 45-61, Le Caire, 2008. .:«A Late Middle Kingdom Offering Table Cairo Temp. №. 25.10.17.1», MDAIK 62,

2006, 1-6.

cABD ’EL-cAL, S.: «A Family Stela from Kafr El-Gabal», GM 171, 1990, 7-11.

cABD 'EL- MAGIUD, Z. R.: «Two Painted Wooden Stelae from the Cairo Museum, (JE18651\& JE 4886) ", SHEDET 2, 2015, 76 - 86.

'ABD 'EL-RAHIEM, M.: «The Treasurer of the King of Lower Egypt Meru», SAK 31, 2003, 1-8.

cABD 'EL- RAZIQ, A.: «A Middle Kingdom Funerary Stela of A Woman at Al- Salam School Museum, Assiut», JEA 99, 2013, 275-281.

cAFFARA, M.: «A New Kingdom Stela in the National Museum of Antiquities, Leiden», JARCE 46, 2010, 147-157.

'AL-'AYEDI, A.-R.: «Stela Sinai 53: A New Perspective», In Supplément aux Annales du Service des Antiquités de L'Égypte, Cahier No. 34, vol. 1, 57-63, Le Caire, 2005.

cALI, A. A.: «More Unpublished Stelae from Tell Basta and the Earliest Evidence for the Deification of Amenhotep I in the Delta», GM 246, 2015, 5- 15.

'ALI, N. O.: «Three Stelae from Ain-Shams», In the Horizon Studies in Egyptology, vol.3, Edited by BASEM SAMIR 'EL- SHARKAWY, 65-75, Cairo, 2009.

ALLEN, T. G.: Egyptian Stelae in Field Museum of Natural History, Chicago: (Chicago Field Museum Press) 1936.

ALTENMÜllER- KESTING, B.: Reinigungsriten im ägyptischen kult, Hamburg: (Lüdke bei der Uni) 1968.

ALTENMÜLLER, H.: «Die Wanddarstellungen im Grab des Mehu in Saqqara», AV 42, 1998.

ASSEM, R.: «Stela JE 34542, Cairo Museum», JARCE 48, 2012, 185- 189. .: «Stela of Ameneminet (TN. 10/6/24/8) », MDAIK 62, 2006, 63-66.

cATALLAH, M.: «Eine Stele aus dem Mittleren Reich im Ägyptischen Museum Kairo », In Supplément aux Annales du Service des Antiquités de L'Égypte, Cahier, N. 34 , vol. 1, 151-158, Le Caire, 2005.

.: «Eine Pyramidionstele eines Trompeters aus dem Ägyptischen Museum in Kairo», OLA 150/1, 2007, 97- 108.

BAKRY, H. S. K.: « Two New- Kingdom Stelae», ASAE 57, 1962, 9-14.

BALIGH, R.: «Three Middle Kingdom Stelae from the Egyptian Museum in Cairo», JARCE 44, 2008, 169184.

BAZIN, L. \& 'EL-ENANY, K.: «La stèle d'un “Chancelier du roi et Prophéte d'Amon de la fin du Moyen Empire à Karnak, (Caire JE. 37507) », Karnak 13, 2010, 1-23.

BENNETT, C. J. C.: «Growth of the htp-dII- Nsw Formula in the Middle Kingdom», JEA 27, 1941, 77-82. «Motifs and Phrases on Funerary Stelae of the Later Middle Kingdom», JEA 44, 1958, 120-121.

BIERBRIER, M. L.: The British Museum: Hieroglyphic Texts from Egyptian Stelae, vol.12, London (British Museum Press) 1993.

The British Museum: Hieroglyphic Texts from Egyptian Stelae, vol.10, London: (British Museum Press) 1982. 
BOESER, A.: Beschreibung der Aegyptischen Sammlung des Niederländischen Reichsmuseums der Altertümer in Leiden, Stelen, vol. 3, Leiden, 1913.

BORGHOUTS, J.: «Libation», LÄ 3, 1980, 1014-1015.

BOTHMER, B.: Egyptian Art, Oxford (Oxford University Press) 2004.

BROVARSKI, E. J.: «An Unpublished Stele of the First Intermediate Period in the Oriental Institute Museum», JNES 32/4, 1973, 453-465.

BRUNNER-TRAUT, E.: «Lotos», LÄ 3, 1980, 1091-1096.

CHERPION, N.: «Le (Cone d'Onguent), Gage de Survie», BIFAO 94, 1994, 79-106.

DARESSY, M. G.: «Inscriptions Hiéroglyphiques du Musée d'Alexandrie», ASAE 5, 1904, 113-128.

DAVIES, N de G.: The Tomb of Rekh-Mi-RE at Thebes, vol. 2, New York: (Arno Press) 1973.

DAVIES, N de G \& DAVIES, Nina de G.: The Tombs of Two Officials of Tuthmosis the Fourth (Nos.75 and 90), London: (Oxford University Press) 1923.

DAVIES, N. de G \& GARDINER, A. H.: The Tomb of Antefoker, Vizier of Sesostris I, and of His Wife, Senet, London (William Clowes and Sons) 1920.

DEMARÉE, R. J.: The 3h ikr n R` stelae; on Ancestor Worship in Ancient Egypt on Ancestor Worship in Ancient Egypt, Egyptologische Uitgaven 3, Leiden (Universiteit van Amsterdam) 1983.

DERCHAIN-URTEL, M.-T.: «Osiris im Fadenkreuz», GM 156, 1997, 47-54.

DORN, A. \& PAULIN-GROTHE, E.: «Die Stele Sen(y) nefers und Grabkegel_(Cones) aus dem tal der Könige, Die Geschichte Ortsfremder Objekte», GM 222, 2009, 9-11.

DUQUESNE, T.: The Jackal Divinities of Egypt I: From the Archaic Period to Dynasty X, Oxfordshire Communications in Egyptology 6, London (Darengo publications) 2005.

DZIOBEK, E.: «Das Grab des Ineni Theban Nr. 81», AV 68, 1992.

EL-BANNA, E.: «Deux Compagnons de Métier sur une Stéle Inédite», JEA 76, 1990, 175-178.

EL-GABRY, D.: «A Late Middle Kingdom Private Stela of the Priests of Hathor (Cairo Museum CG. 20780», JARCE 51, 2015, 266-275.

EL-SAADY, H.: «Two Heliopolitan Stelae of the New Kingdom», ZÄS 122, 1995, $101-104$.

ERMAN, A.: «Zum Namen des Osiris», ZÄS 46, 1967, 92-95.

ERMAN, A. \& GRAPOW, H. (Eds.): Wörterbuch der Ägyptischen Sprache I-V, Leipzig (J. Hinrichs) 19261931.

FAULKNER, R. O.: The Ancient Egyptian Pyramid Texts, Oxford: (Clarendon Press) 1969.

.: A Concise Dictionary of Middle Egyptian, Oxford: (Ashmolean Museum Press) 1981.

FISCHER, G.: «A God and A General of the Oasis on a Stela of the Late Middle Kingdom», JNES 16, 1957, 223-235.

., The Tomb of IP at el Saff, New York: (Metropolitan Museum of Art) 1996.

FRANKE, D.: «The Middle Kingdom Offering Formulas A challenge», JEA 89, 2003, 54-57.

FREED, R.: «Stela Workshops of Early Dynasty 12», in Studies in Honor of William Kelly Simpson, vol. 1, Edited by PETER DER MANUELIAN, 297-336, Boston, 1996.

GABALLA, G. A.: «False - door Stelae of some Memphite Personnel», SAK 7, 1979, 41-52.

GARDINER, A.: Egyptian Grammar, London: (Oxford University Press) 1950.

GREEN, L.: «Hairstyles», In The Oxford Encyclopedia of Ancient Egypt, vol.2, Edited by DONALD B. REDFORD, 73-76, Cairo: (AUC Press) 2001. 


\section{Gehan Roshdy \& Khaled Mohamed Abou al-Elia}

--aclothing and Personal Adornment », In The Oxford Encyclopedia of Ancient Egypt, vol.1, Edited by DONALD B. REDFORD, 274-279, Cairo: (AUC Press) 2001.

HALLMANN, A.: «Three Unusual Stelae from Abydos», JEA 101, 215, 131-152.

HART, G.: The Routledge Dictionary of Egyptian Gods and Goddesses, London and New York (Taylor \&Francis Group) 2005.

HARTWIG, M. K.: Tomb Painting and Identity in Ancient Thebes, 1419-1372 BCE, Brussels: (Brepols Publishers) 2004.

HERMANN, A., «Die Stelen der Thebanischen Felsgräber der 18 Dynastie», ÄF 11, 1940.

HODJASH, S. \& BERLEV, O.: The Egyptian Reliefs and Stelae in the Pushkin Museum of Fine Arts, Moscow, Leningard (Aurora Art Publishers) 1982.

HÖLZL, R.: «Round- Topped Stelae from the Middle Kingdom to the Late Period. Some Remarks on the Decoration of Lunettes», SCIE 1, 1992, 258-289. $\therefore$ «Stelae» In the Oxford Encyclopedia of Ancient Egypt, vol. 3, Edited by DONALD B. REDFORD, 319-324, Cairo (AUC Press) 2001.

ILIN-TOMICH, A. : «A Twelfth Dynasty Stela Workshop Possibly from Saqqara», JEA 97, 2011, 117-126.

$\therefore$ «Changes in the Htp-di-nsw Formula in the Late Middle Kingdom and the Second Intermediate Period», ZÄS 138, 2011, 20-34.

JAMES, T.: The British Museum: Hieroglyphic Texts from Egyptian Stelae, vol.9, London: (British Museum Press) 1970.

JOSEPHSON, J. A.: Catalogue Général of Egyptian Antiquities in the Cairo Museum NRS. 48601- 48649, Statues of the XXV th and XXVI th Dynasties, Cairo (The Supreme Council of Antiquities Press) 1999.

KUHLMANN, K. P.: Der Thron im Alten Ägypten, Glückstadt (J. J Augustin) 1977.

LABRIQUE, F.: «Two Monuments of the high Steward Senaa-Ib of the Middle Kingdom», RdE 54, 2003, 270-278.

LACAU, M. P.: Stèles du Nouvel Empire, in Catalogue général des antiquités égyptiennes du Musée du Caire, Nos. 34001-34189, Le Caire, 1909.

MACADAM, L.: The Temples of Kawa, vol. I, London (Oxford University Press) 1949.

LANDGRÀFOVÀ, R.: It is My Good Name That you should Remember: Egyptian Biographical Texts on Middle Kingdom, Prague, 2011.

LEITZ, CH.: Lexikon der Ägyptischen Götter und Götterbezeichnungen, vol.2, OLA 111, 2002.

: Lexikon der Ägyptischen Götter und Götterbezeichnungen, vol. 5, OLA 114, 2002.

LEPROHON, R. J.: «The Offering Formula in the First Intermediate Period», JEA 76, 1990, 163-164.

LICHTHEIM, M.: «The Stela of Taniy. CG.20564 its Date and its Character», SAK 16, 1989, 203-215.

LURKER, M.: The Gods and Symbols of Ancient Egypt, London (Thames and Hudson) 1980.

MALAISE, M.: «La Position de la Femme sur les Steles du Moyen Empire», SAK 5, 1977, 183-198.

MARÉE, M.: «A Sculpture Workshop at Abydos from the Late Sixteenth or Early Seventeenth Dynasty», in the Second Intermediate Period, OLA. 192, Edited by MARCEL MARÉE, 241-281, Leuven, 2010.

METAWI, R.: «The Stela of the Chief Interior - Overseer to the Treasurer Hrw-nfr (Cairo Museum CG 20563)», JARCE 44, 2008, 141-151.

$\therefore$ «An Interesting New Kingdom Stela from Thebes Cairo Museum (CG.34045)», JARCE $51,2015,277-284$.

MOURSI , M.:« Two Ramesside Stelae From Heliopolis», GM 105, 1988, 59 - 64. 
«Corpus der Mnevis-Stelen und Untersuchungen zum Kult der Mnevis-Stiere in Heliopolis I», SAK 14, 198, 225-237.

OBSOMER, C. : «di.f prt-xrw et la filiation $m s(t) . n /$ ir $(t) . n$ comme critères de datation dans les textes du Moyen Empire», In Individu, Société et Spiritualité dans l'Égypte Pharaonique et Copte, édits par CHRISTIAN CANNUYER et JEAN- MARIE KRUCHTEN, 163-196, Bruxelles, 1993.

PESTMAN, P.: Marriage and Matrimonial Property in Ancient Egypt, Leiden: (E. J. Brill) 1961.

PFLÜGER, K.: «The Private Funerary Stelae of the Middle Kingdom and Their Importance for the Study of Ancient Egyptian History», JAOS 67, 1947, 127-135.

RADWAN, A.: «Six Ramesside Stelae in the popular Pyramidion - Form», ASAE 71, 1987, 223-228.

«Darstellungen der Aufgehenden Sonne auf Einigen Stelen der Ramessidenzeit», In Studien zu Sprache und Religion Ägyptens, vol.2, 823-827, Göttingen , 1984.

$\therefore$ «The Stela Louvre C211», BACE 21, 2010, 99-114.

RANKE, H.: Die Ägyptischen Personennamen, vol.1, Glückstadt (J. J.Augustin) 1935.

RAUE, D.: Heliopolis und das Haus des Re, Berlin (Achet-Verl) 1999.

ROBINS, G.: «Hair and Construction of Identity in Ancient Egypt, C. 1480 - 1350 B.C.», JARCE 36, 1999, 55-69.

$\therefore$ «The Relationships Specified by Egyptian Kinship Terms of the Middle and New Kingdom», CdE 54, 1979, 197- 217.

ROEDER, G.: Aegyptische Inschriften aus den Staatlichen Museum zu Berlin, vol.2, Leipzig, 1924.

RUSSMANN. E. R.: Eternal Egypt, Masterworks of Ancient Art from the British Museum, California (University of California Press) 2001.

SAIED, A.: «Eine Schöne Stele des Bürgermeisters , šdj it. $f^{\prime \prime}$ aus dem Ägyptisches Museum, Kair» In Egyptian Museum Collections around the World, vol.2, Edited by MAMDOUH ELDAMATY \& MAI TRAD, Cairo (AUC press) 2002.

SALEH, H.: Investigating Ethnic and Gender Identities as Expressed on Wooden Funerary Stelae from the Libyan Period (C.1069-715B.C.E.) in Egypt, Oxford (Archaeopress) 2007.

SALEH, J. M.: Les Antiquités Égyptiennes de Zagreb, Paris (Walter de Gruyter Gmbh) 1970.

SAMUAL, D.: «Bread», In The Oxford Encyclopedia of Ancient Egypt, vol.1, Edited by DONALD B. REDFORD, 196-198, Cairo: (AUC Press) 2001.

SEIPEL, W.: Ägypten. Götter, Gräber und die Kunst, vol.1, Linz, 1989.

SELIM, H.: «Three Identical Stelae from the End of the Twelfth or Thirteenth Dynasty», SAK 29, 2001, 319-330.

.$:$ «The Stela of $t 3-{ }^{-} b^{\top} t$ in the Cairo Museum», In Institut francais d'archéologie orientale: Bibliothéque d'Étude 138, 253-258, Le Caire, 2003.

.$:$ «An Eleventh Dynasty Stela in the Cairo Museum (Cairo Temp. 27.4.22.5)», MDAIK 57, $2001,257-269$.

.: «The Stela of $H r-w \underline{d} w$ in the Cairo Museum (JE .41332)», SAK 28, 2000, 243-256.

SHALABY, M. A.: «The Stela of W3h - hrt- nht (JE .57112)», SHEDET 3, 2016, 24-33.

SILVERMN, D.P. \& BROVARSKI, E.: Searching for Ancient Egypt, New York (Cornell University Press) 1997.

SIMPSON, W. K.: Giza Mastabas, The Mastabas of Qar and Idu, vol. 2, Boston (Eastern Press INC.) 1976.

SMITHER, P. C.: «The Writing of htp- di- nsw in The Middle and New Kingdoms», JEA 25, 1939, 34-37. 


\section{Gehan Roshdy \& Khaled Mohamed Abou al-Elia}

SMITHER, P. C. \& DAKIN, A. N.: «Stelae in the Queen's College, Oxford», JEA 25, 1939, 157-165.

STEFANOVIĆ, D.: «Four Middle Kingdom Stelae from the National Archaeological Museum, Athens», JEA 96, 2010, 207-2015.

." «Offerings for the KAS of Six Ladies (British Museum Stela No. 1679», Journal of Classical Studies Matica Srprska 11, 2009 A.

.: The Non-Royal Regular Feminine Titles of the Middle Kingdom and Second Intermediate Period: Dossiers, London: (Golden House Publications) 2009 B.

STEWART, H. M.: Egyptian Stelae, Reliefs and Paintings, vol.1, London (Aris \& Phillips Ltd.) 1976.

TEETER, E.: «A Stela of the Family of Khaemtir (i) and the Scribe Qenherkhepshef (i) (Chicago OIM E 14315)», JARCE 50, 2014, 147-159.

«Inside The Temple: The Role and Function of Temple Singers» in The Life of Meresamun, A Temple Singer in Ancient Egypt, Edited by EMILY TEETER \& JANET H. JOHNSON, 25-29, Chicago: (The Oriental Institute Museum Publication) 2009.

VALBELLE, D.: «Témoignages du Nouvel Empire sur les cultes de Satis et d'Anoukis á Éléphantine et á Deir 'El-Médineh», BIFAO 75, 1975, 123-145.

WARD, W. A.: Index of Egyptian Administrative and Religious Titles of the Middle Kingdom, Beirut (AUB Press) 1982.

WESTENDORF, W.: Ältägyptische Darstellungen des Sonnenlaufes auf der abschüssigen Himmelsbahn, MÄS 10, 1966.

WILKINSON, R. H.: The Complete Gods and Goddesses of Ancient Egypt, London (Thames \& Hudson) 2003. 


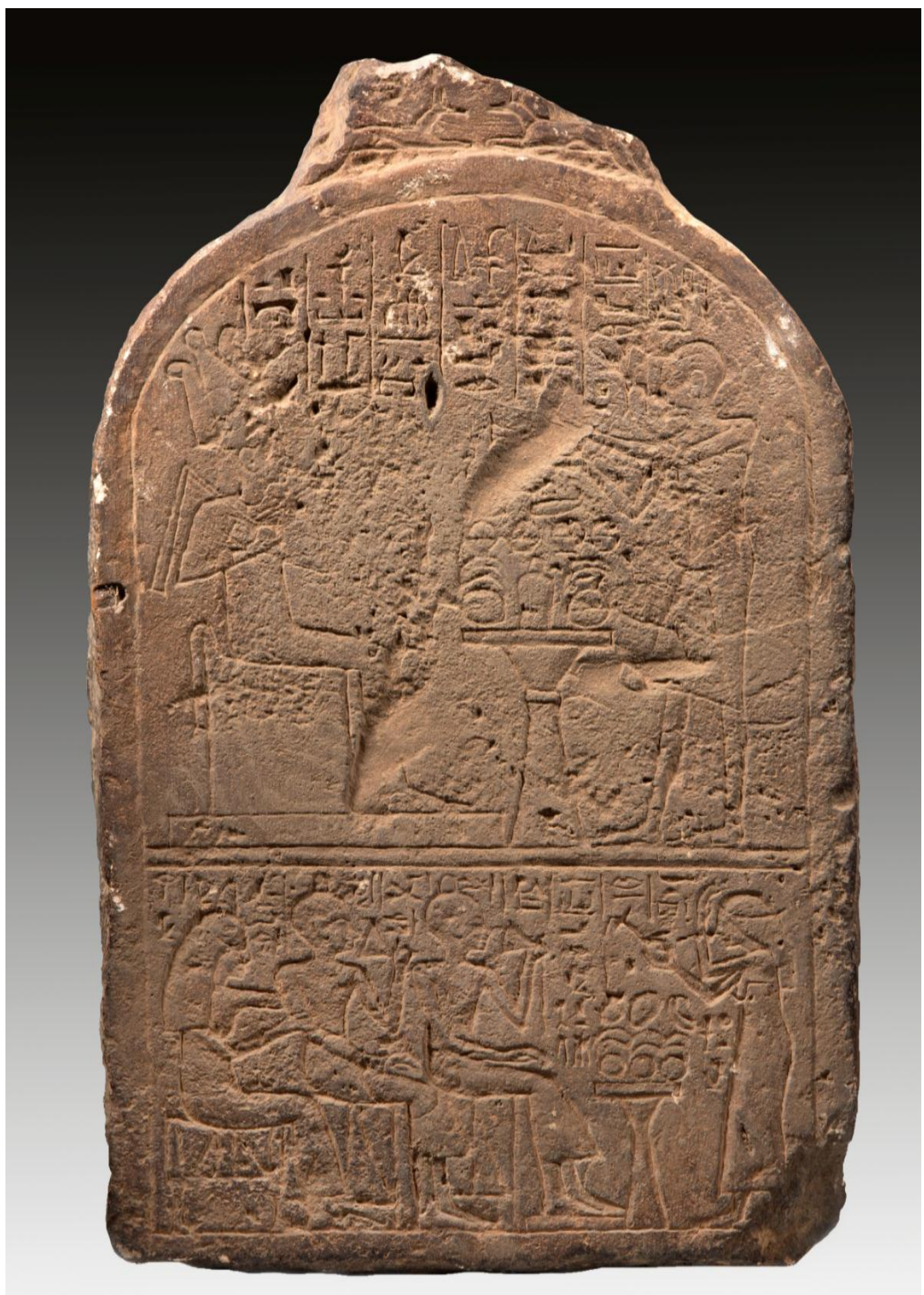

[FIGURE 1]: Stela of Pth-ms (in cArab 'El-Hesn magazine at 'El-Matariya under registration №. 235). Photo taken by Marion Wenzel 


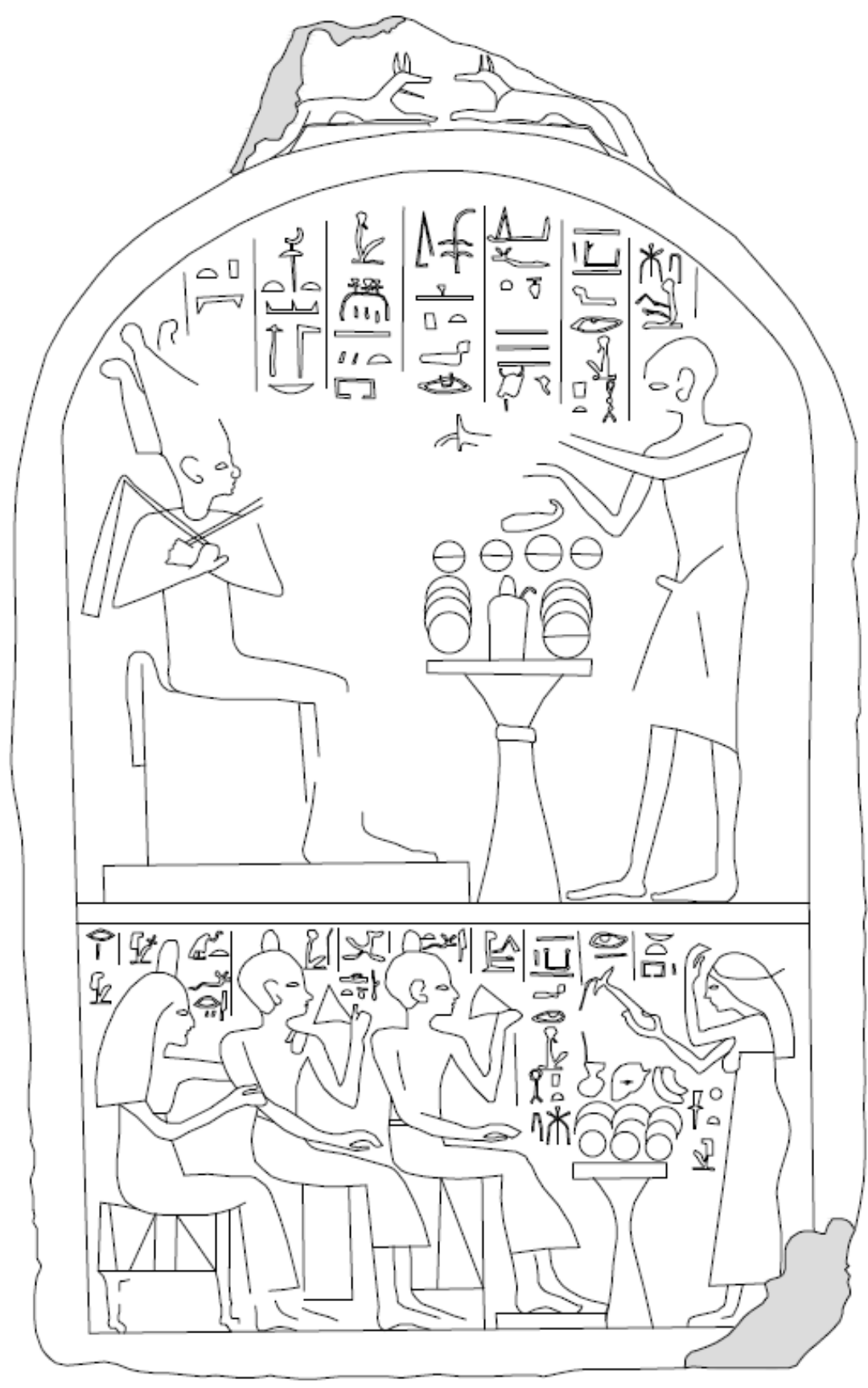

Done by Rasha cAbdelhafez 


\title{
لوحة جنائزية لبتاح مس من عصر الرعامسة فى هليويوليس
}

\author{
جيهان رشدى محمد وخالا محمد أبو العلا

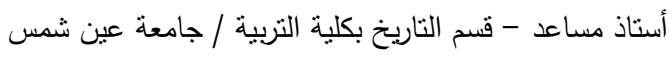 \\ مدير عام موقع المطرية وعين شمس الأثرى بوزارة الآثار .
}

\begin{abstract}
الملخص
تنتاول الورقة الثالية دراسة ونشر لوحة جنائزية لرجل يُدعى بناح مس، وقد عُثر عليها فى هليوبوليس وعلى وجه التحديد فى المنطقة

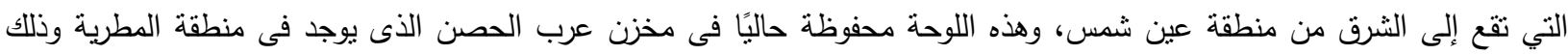
تحت رقم تسجيل هبr، وهى لوحة مصنوعة من الحجر الجيرى، وتُعتبر خالية تمائًا من أى أثار للألوان بها. على الرغم من كون هذه اللوحة فى حالة جيدة من الحفظ إلا أنه يوجد بها بعض الأجزاء المفقودة، وتتمتل هذه الأجزاء فيما يلى ذكره: النصف العلوى من الثنكل

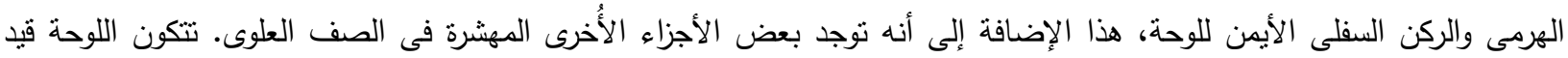

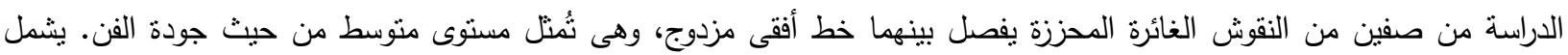

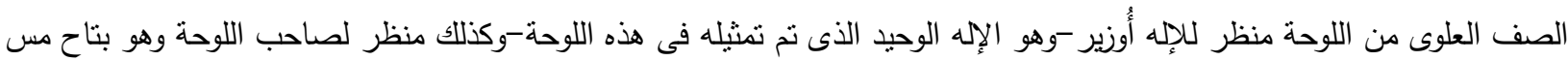

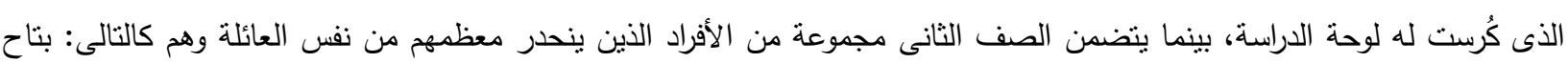

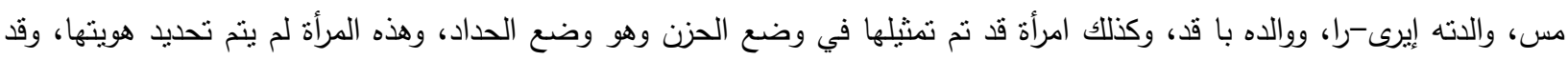

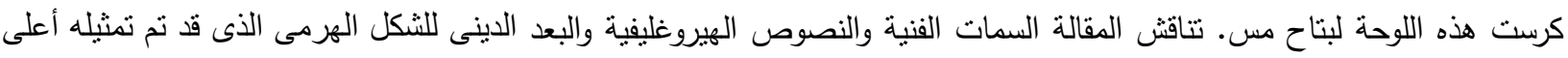

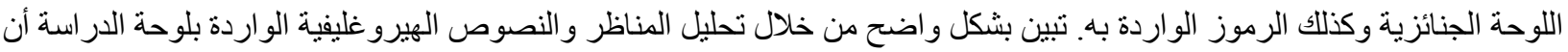

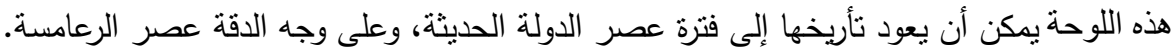

الكلمات الدالة: بتاح مس، أُوزير ، الثكل الهرمى، انوبيس، عصر الرعامسة، لوحة جنائزية، هليوبوليس.
\end{abstract}

